\title{
Buellia nordinii, a new triseptate species from Venezuela
}

\author{
Mireia GIRALT, Klaus KALB and John A. ELIX
}

\begin{abstract}
Buellia nordinii, a new muscicolous or lignicolous species characterized by a blastidiate thallus containing atranorin, apothecia with a fine granular surface, markedly enlarged paraphyses tips and large triseptate ascospores is described from Venezuela. The species grows in very humid situations near the ground in open paramo vegetation at high elevations. It is compared with other known asexually reproducing and triseptate Buellia taxa.
\end{abstract}

Key words: Lecanoromycetes, lichenized fungi, Physciaceae, South America, taxonomy

\section{Introduction}

A very characteristic specimen of Buellia was found growing with Rinodina fuscoisidiata Giralt et al. (2010: 3, sub Buellia aff. proximata), an isidiate, muscicolous taxon recently described from high altitudes in the Paramo vegetation of Venezuela (Giralt et al. 2010). The presence of additional specimens in the herbarium of the second author (hb. K. Kalb) allowed detailed morphological and chemical studies which have shown that they can be clearly distinguished from all other known triseptate Buellia taxa by the larger triseptate ascospores and the markedly enlarged apical cells of the paraphyses which give to the surface of the apothecia a particular granular appearance. These specimens are described as a new species below.

\section{Materials and Methods}

The specimens were examined by standard techniques using stereoscopic and compound microscopes. Only free ascospores lying outside the asci have been measured. Measurements were made on material

M. Giralt: Departament de Bioquímica i Biotecnologia (Àrea de Botànica), Facultat d'Enologia de Tarragona, Universitat Rovira i Virgili, Marcel lí Domingo s/n, 43007, Tarragona, Spain. Email: mireia.giralt@urv.cat K. Kalb: Lichenologisches Institut Neumarkt, Im Tal 12, D-92318 Neumarkt, Germany.

J. A. Elix: Research School of Chemistry, Building 33, Australian National University, Canberra, ACT 0200, Australia. mounted in water at $\times 1000$ magnification. Mean value (M) and standard deviation (SD) were calculated and the results are recorded as (minimum value observed) $\mathrm{M} \pm \mathrm{SD}$ (maximum value observed). $\mathrm{M}, \mathrm{SD}$ and $n$ (the total number of ascospores measured) are given within parentheses. The terminology used for the asci follows Rambold et al. (1994), for the ascospore-types and ascospore ontogeny, Giralt (2001) and for the proper exciple-type, Bungartz et al. (2007).

Chemical constituents were identified by standardized thin layer chromatography and high performance liquid chromatography (HPLC) (Elix et al. 2003).

\section{The Species}

\section{Buellia nordinii Giralt, Kalb \& Elix sp. nov.}

Thallus muscicola vel lignicola, et in et supra substrato crescens, fuscus, atranorinum in vestigiis continens. Specimina in ligno crescentia normaliter blastidios formantia. Apothecia lecideina, nigra. Excipulum proprium typo aethalea. Cellulae apicales paraphysum usque ad $9-10 \mu \mathrm{m}$ diametro auctae, parte superne fuscae. Ascosporae (1-2)-3-septatae, (25-)28.4-35.8 $(-42) \times(10-) 11 \cdot 8-15 \cdot 5(-18) \mu \mathrm{m}$; paries interioris apicaliter et ad basim septorum incrassatus, ontogenia typo A. Conidia bacilliformia, $(2-) 3-4 \times c .1 \mu \mathrm{m}$.

Typus: Venezuela, Mérida, distr. Libertador, Pico Espejo, SE von Mérida, Loma Redonda, $4200 \mathrm{~m}$, $8^{\circ} 35^{\prime} \mathrm{N} ; 71^{\circ} 00^{\prime} \mathrm{W}$, on very soft and decomposed wood, 8 \& 10 August 1989, K. \& A. Kalb (hb. Kalb 23952holotypus; GZU, hb. Kalb 34813-isotypi).

\section{(Figs 1 \& 2)}

Thallus lignicolous or muscicolous, developing beneath the uppermost layers of the substratum (endosubstratal) or episubstratal, brown, thin; in both cases formed of 


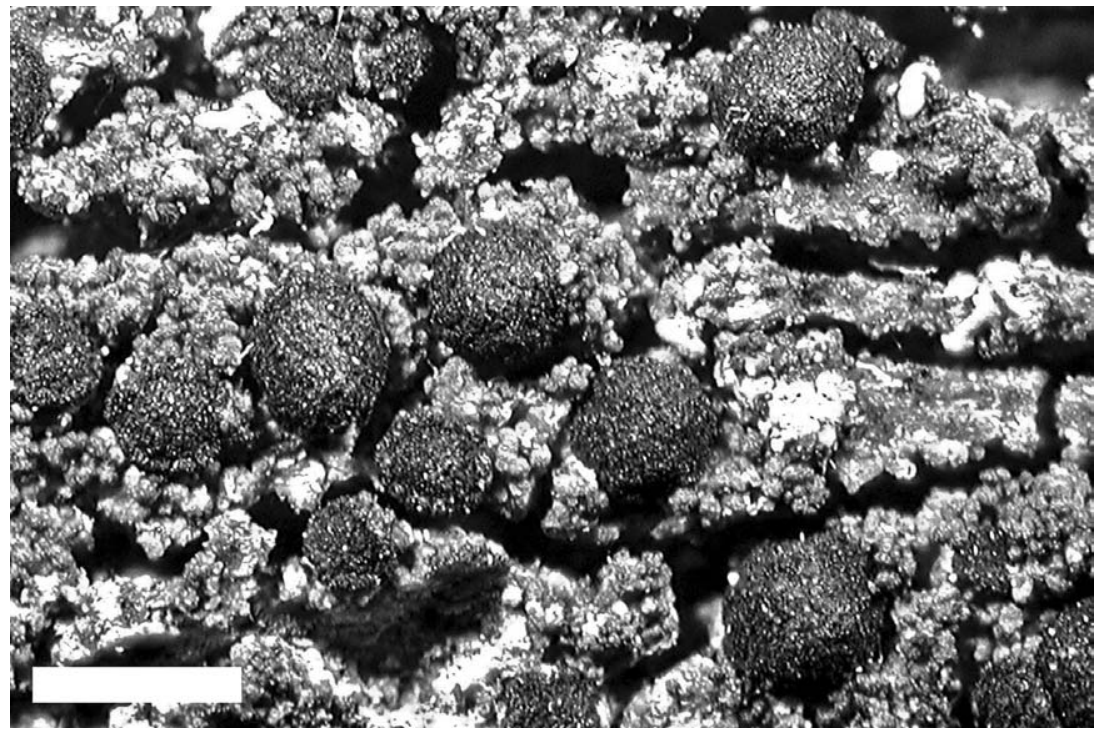

FIG. 1. Buellia nordinii, blastidiate thallus with apothecia (note the granular surface) growing on lignum (holotype). Scale $=1 \mathrm{~mm}$.
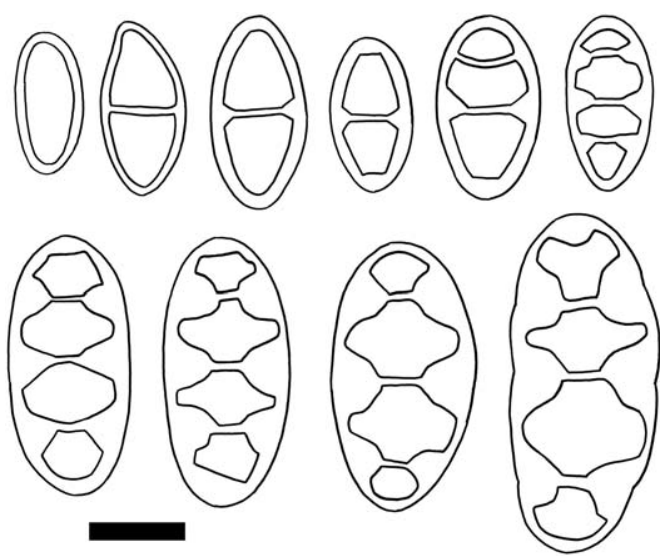

FIG. 2. Buellia nordinii, ascospore ontogeny of type A and ascospore variability (holotype). Scale $=10 \mu \mathrm{m}$.

\pm globose units of $70-120 \mu \mathrm{m}$ diam. composed of a paraplectenchymatous tissue with cells of $3-5(-7) \mu \mathrm{m}$ diam. intermixed with chlorococcoid algal cells, 8-15 $\mu \mathrm{m}$ diam. Outermost (cortical) cells surrounding the globose units brown pigmented, up to $9 \mu \mathrm{m}$ diam.. When episubstratal the globose units develop into blastidia; blastidia scattered to usually contiguous, forming a continuous reddish to dark brown, shiny, granulose crust. The anatomy of the blastidia is identical to that of the \pm globose units of the non-blastidiate, muscicolous thalli and of the endosubstratal part of the lignicolous thalli. All thallus structures are non-amyloid.

Apothecia lecideine, black, with a fine granular surface (a somewhat soft and spongy appearance, Fig. 1), (0.2-)0.3-0.6 $(-0 \cdot 8) \mathrm{mm}$ diam., discrete to rarely crowded and coalescing, sessile and constricted at the base from the beginning when belonging to endosubstratal or muscicolous thalli or adnate when the thallus is an entirely blastidiate crust. Proper margin thick, prominent in young apothecia, becoming thinner, finally excluded. Disc concave at first, then flat and finally convex, epruinose. Proper exciple aethalea-type (Bungartz et al. 2007), laterally 10-30(-50) $\mu \mathrm{m}$ thick, expanded to 40-60 $(-75) \mu \mathrm{m}$ below, inner part hyaline to brownish, outermost part brown with cells with dark brown caps and markedly enlarged, like the apical cells of the paraphyses. Hymenium colourless, 100-120 $\mu \mathrm{m}$ high, not inspersed with oil droplets. Epihymenium brown. Hypothecium 100-150 $\mu \mathrm{m}$ deep, dark brown, upper part with an olivaceous tinge. Paraphyses slender, $1-1 \cdot 2 \mu \mathrm{m}$ wide, the apical cells 
markedly enlarged, up to 9-10 $\mu$ m wide, with dark brown cap. Asci Bacidia-type (Rambold et al. 1994), 8-spored but very often with only (2-)3-4 ascospores fully developed. Ascospores (1-2)-3-septate, $(25-) 28 \cdot 4-35 \cdot 8(-42) \times(10-)$ $11 \cdot 8-15 \cdot 5(-18) \mu \mathrm{m}(\mathrm{M}=32 \times 13.5 \mu \mathrm{m} ; \mathrm{SD}=$ $3.7 / 1.8 \mu \mathrm{m} ; n=73)$, with inner walls slightly thickened at the apices and very pronounced at septa, when mature slightly constricted at septa; outer wall faintly microrugulate (visible at $\times 1000)$. Longitudinal septa never present. Ontogeny of type A (Giralt 2001) (Fig. 2).

Pycnidia rare, subimmersed, globose, unilocular, < $0.1 \mathrm{~mm}$ diam., ostiole dark brown with cells like the apical cells of the paraphyses; conidiogenous cells mainly apical but also intercalary (cf. conidiophoretype V, Vobis 1980). Conidia bacilliform, $2-3(-4) \times$ c. $1 \mu \mathrm{m}$.

Chemistry. K-, C-, KC-, Pd-, UV-. The two specimens analysed (GZU, hb. Kalb 34813-isotype, hb. Kalb 34831) contain traces of atranorin.

Etymology. The species is named in honour of Dr Anders Nordin, Uppsala, Sweden, for his excellent revision of the pluriseptate species of Buellia.

Ecology and distribution. The new species is known only from two localities in Merida province in Venezuela growing on very decomposed lignum and on mosses. At the type locality a sterile, sorediate taxon containing xanthones grows intermixed with the new species. Other accompanying species included Tetramelas regiomontanus Marbach, Rinodina stictica Sheard \& Tønsberg and $R$. fuscoisidiata Giralt, Kalb \& Elix. These species grow in very humid situations near the ground in open paramo vegetation at elevations of 3500 and $4200 \mathrm{~m}$.

Observations. Buellia nordinii is characterized by the endosubstratal to episubstratal thin, brown thallus which usually becomes entirely blastidiate (when growing on lignum), the presence of traces of atranorin, the markedly enlarged apical cells of the paraphyses which give to the apothecia their soft and porous appearance, and the large, tri- septate ascospores $(M=32 \times 13.5 \mu \mathrm{m})$, with inner apical and septal wall thickenings and an ontogeny of type A.

Among all the other known triseptate Buellia s. lat. species (Nordin 1996, 2000), Buellia nordinii together with the terricolous Tetramelas graminicola (Øvstedal) Kalb and T. geophilus (Sommerf.) Norman have the largest ascospores. The two Tetramelas Norman species are clearly distinguished by the presence of xanthones (6-Omethylarthothelin) and ascospores which lack internal wall thickenings. Similarly, T. triphragmioides (Anzi) A. Nordin \& Tibell has much smaller triseptate ascospores while T. insignis (Nägeli ex Hepp) Kalb has large ascospores, but they very rarely become triseptate (Marbach 2000; Kalb 2004; Nordin 2004; Nordin \& Tibell 2005). The species of Hafellia Kalb, H. Mayrhofer \& Scheid. species belong to Buellia s. str. since the type species of Buellia is Buellia (= Hafellia) disciformis (Fr.) Mudd. (cf. Gams 2004). Hafellia bispora Sheard, H. disciformis (Fr.) Marbach \& H. Mayrhofer and $H$. sanguinolenta ( $\mathrm{T}$. Schauer) Hafellner \& Türk are distinguished from $B$. nordinii by the Callispora-type ascospores and the hymenia inspersed with oil droplets (Sheard 1992; Giralt et al. 2002a; Etayo \& Marbach 2003).

The tropical, montane Buellia proximata H. Magn. and B. lauricassiaeoides Aptroot, and the Macaronesian, submontane, $B$. laurocanariensis Giralt, Etayo \& van den Boom, are probably more closely related to B. nordinii. All three taxa have ascospores with internal wall thickenings, but in contrast to $B$. nordinii, the ascospores are significantly smaller $[M=24.3 \times 8.8 \mu \mathrm{m} ; n=80$; $23.2 \times 8.9 \mu \mathrm{m} ; n=10$; and $22.9 \times 8.9 \mu \mathrm{m}$; $n=61$, respectively] and those of the first two species show type-B ontogeny (cf. Imshaug 1955; Aptroot et al. 1997; Nordin 2000; Giralt et al. 2002b). Further, they are corticolous, lack vegetative propagules and have less enlarged paraphyses tips. Additional distinguishing features are the presence of diploicin as well as atranorin in $B$. proximata (Nordin 2000) and B. lauricassiaeoides (J. A. Elix unpublished data), the sporadic presence of longitudinal septa in the ascospores 
of $B$. proximata, the often 4-5-septate ascospores of $B$. lauricassiaeoides and the strongly ornamented ascospore walls (rugulate) of $B$. laurocanariensis.

According to the literature, relatively few Buellia s. lat. species are known to develop vegetative propagules, namely, Amandinea efflorescens (Müll. Arg.) Marbach, Buellia arborea Coppins \& Tonsberg, B. dissimilis (Nyl.) Müll. Arg., B. elizae (Tuck.) Tuck., B. exalbida (Kremp.) Zahlbr., B. griseovirens (Turner \& Borrer ex Sm.) Almb., B. manamiana Diederich, $B$. subfrigida $M$. Inoue, $B$. sorediata (Tuck.) Magn., B. violaceofusca Thor \& Murh and Tetramelas graminicola (Imshaug 1955; Harris 1988; Thor \& Muhr 1991; Tonsberg 1992; Inoue 1993; Aptroot et al. 1997; Marbach 2000; Nordin 2000; Øvstedal \& Lewis Smith 2001; Kalb 2004; Bungartz et al. 2007). None of these species have features that are diagnostic of Buellia nordinii.

Additional specimens examined. Venezuela: Mérida: distr. Rangel, zwischen Laguna Mucubaji und Pico Mucuñuque, etwa $15 \mathrm{~km} \mathrm{SE}$ von Apartaderos, in Paramo-Vegetation, $3500 \mathrm{~m}, 8^{\circ} 45^{\prime} \mathrm{N} ; 70^{\circ} 45^{\prime} \mathrm{W}$, on lignum, 1989, K. E A. Kalb \& López-Figueiras (hb. Kalb 27015); distr. Libertador, Pico Espejo, SE von Mérida, Loma Redonda, $4200 \mathrm{~m}, 8^{\circ} 35^{\prime} \mathrm{N} ; 71^{\circ} 00^{\prime} \mathrm{W}$, on mosses, 1989, K. E A. Kalb (hb. Kalb 34821, 34831-topotypes).

The authors wish to thank Anders Nordin for checking part of the material used in this study and for his helpful comments on it. The first author thanks the 'Comissionat per a la Recerca' (Catalan Government) and the project CGL2007-66734-C03-02/BOS (Spanish Government) for financial support.

\section{REFERENCES}

Aptroot, A., Diederich, P., Sérusiaux, E. \& Sipman, H. J. M. (1997) Lichens and lichenicolous fungi from New Guinea. Bibliotheca Lichenologica 64: 1-220.

Bungartz, F., A. Nordin \& U. Grube (2007). Buellia De Not. In Lichen Flora of the Greater Sonoran Desert Region, Volume 3 (T. H. Nash III, B. D. Ryan, P. Diederich, C. Gries \& F. Bungartz, eds): 113-179. Tempe, AZ: Lichens Unlimited.

Elix, J. A., Giralt, M. \& Wardlaw, J. H. (2003) New chloro-depsides from the lichen Dimelaena radiata. Bibliotheca Lichenologica 86: 1-7.

Etayo, J. \& Marbach, B. (2003) Hafellia alisioae and $H$. gomerana (lichenized Ascomycetes, Physciaceae), two new species from the Canary Islands, with a key to all known corticolous species. Lichenologist 35: 369-375.
Gams, W. (2004) Report of the Committee for Fungi: 11. Taxon 53: 1067-1069.

Giralt, M. (2001) The lichen genera Rinodina and Rinodinella (lichenized Ascomycetes, Physciaceae) in the Iberian Peninsula. Bibliotheca Lichenologica 79: $1-160$.

Giralt, M., Barbero, M. \& Elix, J. A. (2002a) Notes on some corticolous and lignicolous Buellia species from the Iberian Peninsula. Lichenologist 32: 105128.

Giralt, M., Etayo, J. \& van den Boom, P. P. G. (2002b) Buellia laurocanariensis, a new species from the Canary Islands. Lichenologist 34: 203-206.

Giralt, M., Kalb, K. \& Elix, J.A. (2010) Rinodina fuscoisidiata, a new muscicolous, isidiate species from Venezuela. Lichenologist 42: 1-4.

Harris, R. C. (1988) Buellia in North America and central Florida or the virtues and rewards of collections. Evansia 5: 37-45.

Imshaug, H. A. (1955) The lichen genus Buellia in the West Indies. Farlowia 4: 473-512.

Inoue, M. (1993) Buellia subfrigida sp. nov. (Lichens, Buelliaceae) from Lützow-Holm Bay Area and Prince Olav Coast, East Antartica. The asexual sorediate species forming a species pair with $B$. frigida Darb. Nankyoku Shiryô (Antarctic Record) 37: 19-23.

Kalb, K. (2004) New or otherwise interesting lichens II. Bibliotheca Lichenologica 88: 301-329.

Marbach, B. (2000) Corticole und lignicole Arten der Flechtengattung Buellia sensu lato in den Subtropen und Tropen. Bibliotheca Lichenologica 74: 1-384.

Nordin, A. (1996) Buellia species (Physciaceae) with pluriseptate spores in Norden. Symbolae Botanicae Upsalienses 32: 195-208.

Nordin, A. (2000) Taxonomy and phylogeny of Buellia species with pluriseptate spores (Lecanorales, Ascomycotina). Acta Universitatis Upsalienses 33: 1-117.

Nordin, A. (2004) New species in Tetramelas. Lichenologist 36: 355-359.

Nordin, A. \& Tibell, L. (2005) Additional species in Tetramelas. Lichenologist 37: 491-498.

Øvstedal, D. O. \& Lewis Smith, R. I. (2001) The lichens of Antarctica and South Georgia. A Guide to Their Identification and Ecology. Cambridge: Cambridge University Press.

Rambold, G., Mayrhofer, H. \& Matzer, M. (1994) On the ascus types in the Physciaceae (Lecanorales). Plant Systematics and Evolution 192: 31-40.

Sheard, J. W. (1992) The lichenized ascomycete genus Hafellia in North America. Bryologist 95: 79-87.

Thor, G. \& Muhr, L.E. (1991) Buellia violaceofusca, a new lichen from Sweden. Lichenologist 23: 11-13.

Tønsberg, T. (1992) The sorediate and isidiate, corticolous, crustose lichens in Norway. Sommerfeltia 14: $1-331$.

Vobis, B. (1980) Bau und Entwicklung der Flechtenpycnidien und ihrer Conidien. Bibliotheca Lichenologica 14: 1-141. 